\title{
Effects on Cell Viability and on Apoptosis in Tumoral (MCF-7) and in Normal (MCF10A) Epithelial Breast Cells after Human Chorionic Gonadotropin and Derivated-Angiotensin Peptides Treatments
}

\author{
Silvana Aparecida Alves Corrêa de Noronha ${ }^{1 *}$, Werica Bernardo ${ }^{2}$, Alexandre Jesus Barros ${ }^{3}$, \\ Clovis Ryuichi Nakaie ${ }^{3}$, Suma Imura Shimuta ${ }^{3}$, Ismael Dale Cotrim Guerreiro da Silva ${ }^{2}$, \\ Samuel Marcos Ribeiro de Noronha ${ }^{1}$
}

${ }^{1}$ Laboratorio de Cirurgia Translacional, Departamento de Cirurgia, Universidade Federal De Sao Paulo/Escola Paulista De Medicina, São Paulo, Brazil; ${ }^{2}$ Laboratório de Ginecologia Molecular, Universidade Federal de São Paulo, São Paulo, Brazil; ${ }^{3}$ Departamento de Biofísica, Universidade Federal de São Paulo, São Paulo, Brazil.

Email: "silaac@globo.com, wericabernardo@gmail.com, cnakaie@unifesp.br, sshimuta@unifesp.br, ismael.dale@gmail.com, labgineco@globo.com.

Received May 20 ${ }^{\text {th }}, 2013$; revised June $22^{\text {nd }}, 2013$; accepted June $30^{\text {th }}, 2013$

Copyright (C) 2013 Silvana Aparecida Alves Corrêa de Noronha et al. This is an open access article distributed under the Creative Commons Attribution License, which permits unrestricted use, distribution, and reproduction in any medium, provided the original work is properly cited.

\begin{abstract}
Angiotensin-(1 - 7) [Ang-(1 - 7)] is an endogenous heptapeptide hormone of the renin-angiotensin system that has antiproliferative properties. The aim of this work was to evaluate the anti-proliferative and pro-apoptotic properties of Ang-(1 - 7) and of Ang-(1 - 7)-substituents 9-fluorenylmethyloxycarbonyl (Fmoc) e Ang II-derivatives containing the TOAC (2,2,6,6-tetramethylpiperidine-N-oxyl-4-amino-4-carboxylic acid) in normal (MCF10A) and in tumoral (MCF7) epithelial mammary cell lines. Both cell lines received an hCG and angiotensin peptides 24-hour treatment, in combination or alone followed by cell viability, apoptosis and cell cycle assays performed by flow cytometer (GUAVA). After hCG, Ang-(1 - 7), hCG + Ang-(1 - 7) and hCG + Ang-(1 - 7)-Fmoc treatments, MCF7 displayed cell viability decrease and mid-apoptosis increase. We also observed cell viability decrease in MCF10A after Ang-(1 - 7), Ang-(1 - 7) Fmoc and hCG + AngII Toac treatments. These cells had an increase in late apoptosis and necrosis after AngII Toac, hCG + Ang-(1 - 7) and hCG + Ang-(1 - 7)-Fmoc treatments. Regarding the cell cycle analysis, we did not observed any changes in cell cycle phases. In summary, cell viability was decreased and apoptosis (initial, mid and late) was increased after hCG and/or Ang-( 1 - 7) peptides treatments. These results point out hCG and Ang-(1 - 7) as effective compounds to inhibit cell proliferation, since they decrease cell viability and increase apoptosis in both normal and in tumoral breast cells, being the effect more pronounced in the tumoral cell line. Our results support the idea of investigating more closely the putative use of these compounds as novel therapeutic agents for breast cancer.
\end{abstract}

Keywords: Angiotensin II; Angiotensin 1 - 7; Angiotensin II Type 1 Receptor (AT1R); Breast Cancer; Apoptosis; Human Chorionic Gonadotropin.

\section{Introduction}

Breast cancer is the most common cancer among American women, except for skin cancers. About one in eight $(12 \%)$ women in the US will develop invasive breast cancer throughout her lifetime. The American Cancer Society's estimates that 226,870 new cases of breast cancer will be diagnosed in 2012 in the United States; about 63,300 new

"Corresponding author. cases of carcinoma in situ (CIS) will be diagnosed and about 39,510 women will die from breast cancer [1].

The renin angiotensin system (RAS) is a hormone widely known for regulating blood pressure. The proteolytic cascade of the RAS begins with the release of renin (REN), an aspartyl protease which cleaves angiotensinogen (AGT) produces Angiotensin I (Ang I), which is hydrolyzed by angiotensin converting enzyme (ACE) and releases Angiotensin II (Ang II); this octapeptide ex- 
erts its functions through its specific membrane receptors, Angiotensin II receptor Type 1 and Type 2 (AGTR1 and AGTR2, respectively) [2]. Most of the physiological effects are attributed to the signaling pathways activated by the AGTR1. However, other components of the reninangiotensin system (RAS) have been described as having mitogenic and angiogenic activities [3,4]. Since angiogenesis and proliferative processes are related to the development, progression and metastasis of cancer, we believe that there might be an association between these other RAS components with cancer [5]. Recent studies have shown that at a local tissue level, the components of the RAS influence tumor growth by changing its microenvironment [6,7]. Angiotensin-(1 - 7) [Ang-(1 - 7)] is an endogenous peptide hormone that functions as a vasodilator [8] with antihypertensive [9], antiproliferative [1012] and antiangiogenic properties [13]. The formation of Ang-(1 - 7) from Ang I requires the action of three tissue endopeptidases: prolyl endopeptidase, neutral endopeptidase and thimet oligopeptidase [14-16]. Ang-(1 - 7) may also be synthesized from Ang II by the action of the ACE2 (Angiotensin converting enzyme 2) [17,18] or from Angiotensin-(1 - 9) [19]. Ang-(1 - 7) may be hydrolyzed by ACE forming Ang-(1 - 5) and Angiotensin(1 - 3) $[20,21]$. The existence of a receptor for Ang-(1 - 7) is controversial. Most studies have shown that this Ang$(1-7)$ exerts its physiologic effects probably through activation of a unique G protein-coupled Ang-(1 - 7) [AT (1 - 7)] receptor encoded by the mas oncogene (mas1) [22].

The aim of this work was to evaluate the anti-proliferative and pro-apoptotic properties of Ang-(1 - 7), of Ang (1 - 7)-FMOC and of Ang II-TOAC analogues in normal (MCF10A) and in tumoral (MCF7) epithelial mammary cells. These cell lines were also treated with Human Chorionic Gonadotropin (hCG), a hormone that elicits life-long refractoriness to carcinogenesis by differentiation of the breast epithelium in order to assess any possible synergistic effect of these compounds.

\section{Materials and Methods}

\subsection{Peptides}

Ang II-TOAC, an Ang II analogue containing the TOAC (2,2,6,6-tetramethylpiperidine-N-oxyl-4-amino-4-carboxylic acid) spin label synthesized by solid phase methodology [23] and Ang-(1 - 7)-FMOC, an Ang-(1 - 7) analogue containing the FMOC (9-fluorenylmethyloxycarbonyl) group was used for protection of the amine function [24]. These peptides were supplied by dr. C.R. Nakaie (department of Biophysics/UNIFESP-BRAZIL). hCG was obtained from Ovidrel $^{\circledR}$.

\subsection{Cell Culture and Treatments}

MCF7 cells (HTB-22, ATCC) were grown in Dulbecco's
Modified Eagle Medium (DMEM), $4.5 \mathrm{~g} / 1$ of glucose, supplemented with $5 \%$ fetal calf serum, $100 \mathrm{U} / \mathrm{mL}$ of penicillin (PAA), and $100 \mathrm{mg} / \mathrm{mL}$ of streptomycin (PAA). MCF10A cells (CRL-10317, ATCC) were cultured in DMEM/F-12 medium (PAA, Carlsbad, CA) supplemented with $10 \mathrm{mg} / \mathrm{mL}$ of human insulin (Sigma, St. Louis, MO), $20 \mathrm{ng} / \mathrm{mL}$ of epidermal growth factor (Sigma, St. Louis, MO), $0.5 \mathrm{mg} / \mathrm{mL}$ of hydrocortisone (Sigma, St. Louis, MO), $5 \%$ horse serum (Invitrogen), $100 \mathrm{U} / \mathrm{mL}$ of penicillin (PAA) and $100 \mathrm{mg} / \mathrm{mL}$ of streptomycin (PAA). All the cells lines employed in this work were cultured at $37^{\circ} \mathrm{C}$ in a humidified atmosphere and $5 \% \mathrm{CO}_{2}$. The following treatments were performed on these cells: control (1); hCG (2); Ang II (3); Ang-(1 - 7) (4); Ang-(1 7)-FMOC (5); Ang II-TOAC (6); hCG + Ang II (7); hCG + Ang-(1 - 7) (8); hCG + Ang-(1 - 7)-FMOC (9); hCG + Ang II-TOAC (10).

\subsection{Flow Cytometer (GUAVA ${ }^{\mathrm{TM}}$ ) Assays}

MCF7 and MCF10A cells were seeded into 24-well plates with DMEM supplemented with $10 \%$ FBS in the absence (control) or presence of hCG. The cells were treated with $20 \mu \mathrm{M}$ of peptide, the most active concentration value [25,26], and Angiotensin-deriveted peptides [Ang-(1 - 7)Fmoc and Ang II-Toac] in the concentration of $10^{-6} \mathrm{M}$. After 24 hours of treatment, it was possible to determine viability index, and percentage of apoptosis, and cell cycle by means of biochemical assays in flow cytometer (Guava EasyCyteTM-Millipore) using kits ViaCount ${ }^{\circledR}$ Guava, Guava Nexin ${ }^{\circledR}$ and cell cycle assay ${ }^{\circledR}$, respectively.

\subsection{Statistical Analysis}

The results for cell proliferation, apoptosis, and cell cycle assays were analyzed by descriptive statistics (means and standard deviation) and inferential statistics through the Student's $t$-test with significance level of $5 \%(\mathrm{p}<0.05)$.

\section{Results}

\subsection{Cell Viability Assays}

MCF-7 cells showed cell viability decrease while the mid-apoptosis increased after Ang-(1 - 7), Ang-(1 - 7)FMOC and hCG + Ang II-TOAC treatments (Figure 1(a)). On the other hand MCF10A cells showed cell viability decrease, while the mid-apoptosis increased after Ang-(1 - 7) and hCG + Ang-(1 - 7)-FMOC treatments (Figure 1(b)).

\subsection{Apoptosis Assays}

Late apoptosis and dead cells ratio increase in MCF-7 cells after hCG, Ang-(1 - 7), and hCG + Ang-(1 - 7)FMOC treatments (Figure 2(a)). Late apoptosis or 


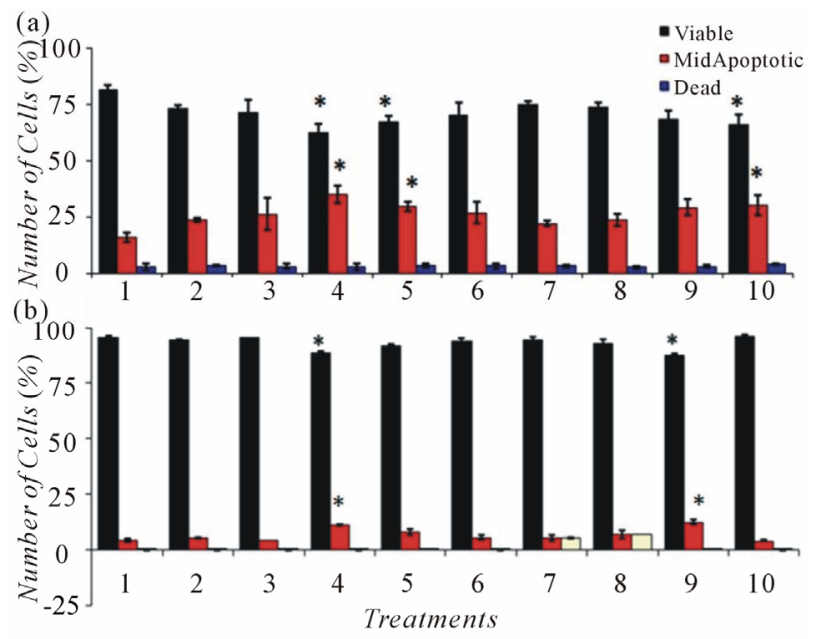

Figure 1. Cell viability analysis after peptides, analogues and hCG treatments in MCF-7 (a) or MCF10A (b) cells. control 1); hCG 2); Ang II 3); Ang-(1 - 7) 4); Ang-(1 7)-FMOC 5); Ang II-TOAC 6); hCG + Ang II 7); hCG + Ang-(1 - 7) 8); hCG + Ang-(1 - 7)-FMOC 9); hCG + Ang II-TOAC (10). ${ }^{*} \mathrm{p}<0.05$ (compared to controls).
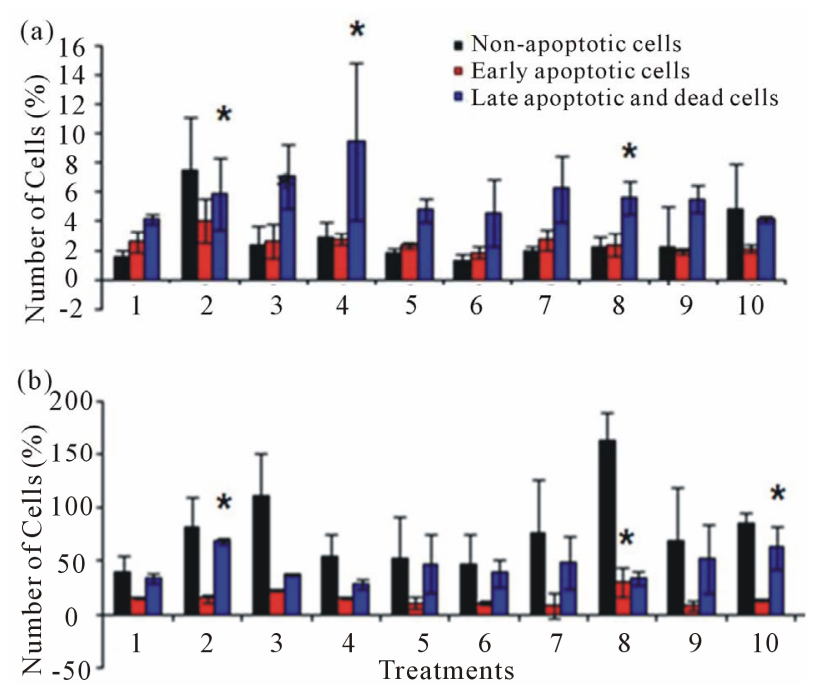

Figure 2. Apoptosis analysis after peptides, analogues and hCG treatments in MCF-7 (a) and in MCF10A (b) cells. control 1); hCG 2); Ang II 3); Ang-(1 - 7) 4); Ang-(1 7)-FMOC 5); Ang II-TOAC 6); hCG + Ang II 7); hCG + Ang-(1 - 7) 8); hCG + Ang-(1 - 7)-FMOC 9); hCG + Ang IITOAC 10). ${ }^{*}<0.05$ (compared to controls).

dead cells increase after hCG treatment while early apoptosis in creases in MCF10A cells after hCG + Ang-(1 7)-FMOC treatment (Figure 2(b)).

\subsection{Cell Cycle Assays}

MCF7 and MCF10A cells did not evidenced alterations for $\mathrm{G} 0 / \mathrm{G} 1$ or $\mathrm{S}$ cell cycle after treatments. Except for hCG that increases G2/M in MCF-7 (Figure 3(a)) and

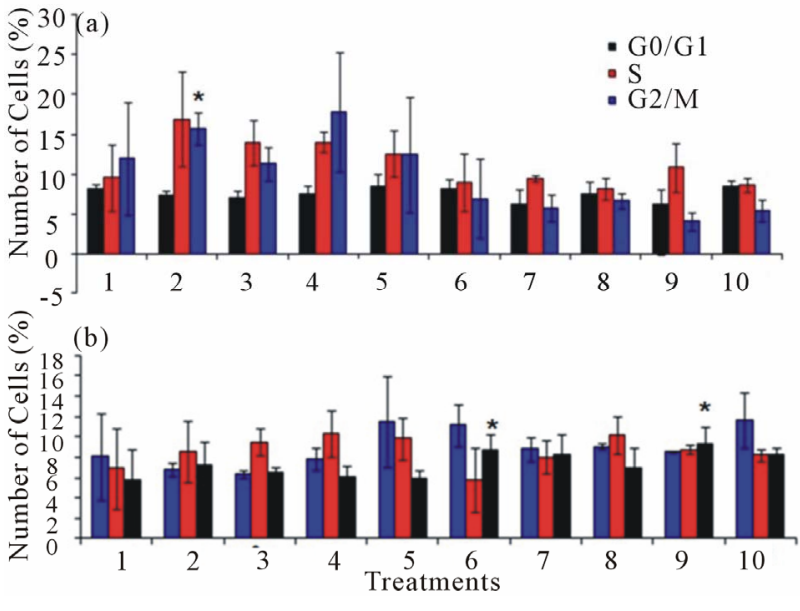

Figure 3. Cell cycle analysis after peptides, analogues and hCG treatments in MCF-7 (a) and in MCF10A (b) cells. control 1); hCG 2); Ang II 3); Ang-(1 - 7) 4); Ang-(1 - 7)FMOC 5); Ang II-TOAC 6); hCG + Ang II 7); hCG + Ang(1 - 7) 8); hCG + Ang-(1 - 7)-FMOC 9); hCG + Ang II-TOAC 10). ${ }^{*} \mathrm{p}<0.05$ (compared to controls).

for Ang II-TOAC and hCG + Ang-(1 - 7)-FMOC that increase G2/M in MCF-10A (Figure 3(b)).

\section{Discussion}

Ang II stimulates proliferation of AT1R-positive breast cancer cells through PI3-kinase/Akt pathway activation [27] and Ang-(1 - 7) has a clinical and pre-clinical activity in vascular sarcomas by reducing HIF-1alpha and PIGF genes expression [28]. In the present study, cell viability was decreased and mid-apoptosis was increased in both tumoral and in normal cells (MCF-7 and MCF10A) after Ang-(1 - 7) and analogs containing TOAC or FMOC treatments. Also, we observed that Ang II containing the TOAC substituent became an anti-proliferative hormone. Late apoptosis and cell death were increased after hCG, Ang-(1 - 7), and Ang-(1 - 7)-FMOC trreatments in MCF-7 cells. Early apoptosis was increased after stimulation with Ang-(1 - 7) and the effects of the peptides containing an FMOC group were powered by hCG in MCF10A cells.

Furthermore, cell cycle changes were not observed after peptide treatments, only hCG increased the stationary phases of the cell cycle (G2/M) in MCF-7 cells. Moreover in MCF10A cells, only the peptides containing the groups FMOC and TOAC triggered this same type of change. Therefore it is possible to say that the TOAC and FMOC substituent groups potentiate the anti-proliferative or proapoptotic effect in both cell types. Moreover we could also observe that Ang II becomes anti-proliferative in these mammary cells when the TOAC group is added to the hormone molecule and finally that hCG enhances the effects of the peptides. 
In summary, cell viability was decreased and apoptosis (initial, mid and late) was increased after hCG and/or Ang-(1 - 7) peptides treatments. These results point out hCG and Ang-(1 - 7) as effective compounds to inhibit cell proliferation, since they decrease cell viability and increase apoptosis in both normal and tumoral breast cells, being the effect more pronounced in the tumoral cell line. Our results support the idea of investigating more closely the putative use of these compounds as novel therapeutic agents for breast cancer.

\section{Acknowledgements}

The work was supported by Grants number 2007 /564800, 2008/54383-0 and 2011/10516-0 from the Sao Paulo Research Foundation (FAPESP)-Brazil.

\section{REFERENCES}

[1] "What Are the Key Statistics about Breast Cancer?" 2013. http://www.cancer.org/cancer/breastcancer/detailedguide/ breast-cancer-key-statistics

[2] P. M. Frossard, M. J. Malloy, G. G. Lestringant and J. P. Kane, "Haplotypes of the Human Renin Gene Associated with Essential Hypertension and Stroke," Journal of Human Hypertension, Vol. 15, No. 1, 2001, pp. 49-55. doi:10.1038/si.jhh.1001107

[3] M. Fujita, I. Hayashi, S. Yamashina, M. Itoman and M. Majima, "Blockade of Angiotensin AT1a Receptor Signaling Reduces Tumor Growth, Angiogenesis, and Metastasis," Biochemical and Biophysical Research Communications, Vol. 294, No. 2, 2002, pp. 441-447. doi:10.1016/S0006-291X(02)00496-5

[4] S. Greco, A. Muscella, M. G. Elia, et al., "Angiotensin II Activates Extracellular Signal Regulated Kinases via Protein Kinase C and Epidermal Growth Factor Receptor in Breast Cancer Cells," Journal of Cellular Physiology, Vol. 196, No. 2, 2003, pp. 370-377.

doi:10.1002/jcp.10313

[5] F. Deshayes and C. Nahmias, "Angiotensin Receptors: A New Role in Cancer?" Trends in Endocrinology \& Metabolism, Vol. 16, No. 7, 2005, pp. 293-299. doi:10.1016/j.tem.2005.07.009

[6] E. I. Ager, J. Neo and C. Christophi, "The Rennin-AngioTensin System and Malignancy," Carcinogenesis, Vol. 29, No. 9, 2008, pp. 1675-1684. doi:10.1093/carcin/bgn171

[7] F. Deshayes and C. Nahmias, "Angiotensin Receptors: A New Role in Cancer?" Trends in Endocrinology \& Metabolism, Vol. 16, No. 7, 2005, pp. 293-299. doi:10.1016/j.tem.2005.07.009

[8] R. A. Santos, M. J. Campagnole-Santos and S. P. Andrade, "Angiotensin-(1 - 7): An Update," Regulatory Peptides, Vol. 91, No. 1-3, 2000, pp. 45-62. doi:10.1016/S0167-0115(00)00138-5

[9] I. F. Benter, D. I. Diz and C. M. Ferrari, "Pressor and Reflex Sensitivity Is Altered in Spontaneously Hypertensive Rats Treated with Angiotensin-(1 - 7)," Hypertension,
Vol. 26, No. 6, 1995, pp. 1138-1144. doi:10.1161/01.HYP.26.6.1138

[10] W. B. Strawn, C. M. Ferrario and E. A. Tallant, "Angiotensin (1 - 7) Reduces Smooth Muscle Growth after Vascular Injury," Hypertension, Vol. 33, No. 1, 1999, pp. 207-211. doi:10.1161/01.HYP.33.1.207

[11] E. J. Freeman, G. M. Chisolm, C. M. Ferrario and E. A. Tallant, "Angiotensin-(1 - 7) Inhibits Vascular Smooth Muscle Cell Growth," Hypertension, Vol. 28, No. 1, 1996, pp. 104-108. doi:10.1161/01.HYP.28.1.104

[12] E. A. Tallant, C. M. Ferrario and P. E. Gallagher, "Angiotensin-(1 - 7) Inhibits Growth of Cardiac Myocytes through Activation of the Mas Receptor," American Journal of Physiology-Heart and Circulatory Physiology, Vol. 289, No. 4, 2005, pp. H1560-H1566. doi:10.1152/ajpheart.00941.2004

[13] R. D. Machado, R. A. Santos and S. P. Andrade, "Opposing Actions of Angiotensins on Angiogenesis," Life Sciences, Vol. 66, No. 1, 2000, pp. 67-76.

[14] R. A. Santos, K. B. Brosnihan, D. W. Jacobsen, P. E. DiCorletto and C. M. Ferrario, "Production of Angiotensin- $(1$ - 7) by Human Vascular Endothelium," Hypertension, Vol. 19, No. 2, 1992, pp. 56-61.

[15] K. Yamamoto, M. C. Chappell, K. B. Broshinan and C. M. Ferrario, "In Vivo Metabolism of Angiotensin I by Neutral Endopeptidase (EC 3.4.24.11) in Spontaneously Hypertensive Rats," Hypertension, Vol. 19, No. 6, 1992, pp. 692-696. doi:10.1161/01.HYP.19.6.692

[16] M. C. Chappell, E. A. Tallant, K. B. Brosnihan and C. M. Ferrario, "Conversion of Angiotensin I to Angiotensin-(1 - 7) by Thimet Oligopeptidase (E.C.3.4.24.15) in Vascular Smooth Muscle Cells," Journal of Vascular Medicine and Biology, Vol. 5, No. 4, 1994, pp. 129-137.

[17] S. R. Tipnis, N. M. Hooper, R. Hyde, E. Karran, G. Christie and A. J. Turner, "A Human Homolog of AngiotensinConverting Enzyme. Cloning and Functional Expression as a Captopril-Insensitive Carboxypeptidase," The Journal of Biological Chemistry, Vol. 275, No. 43, 2000, pp. 33238-33243. doi:10.1074/jbc.M002615200

[18] M. A. Crackower, R. Sarao, G. Y. Oudit, C. Yagil, I. Kozieradzki, S. E. Scanga, et al., "Angiotensin-Converting Enzyme 2 Is an Essential Regulator of Heart Function," Nature, Vol. 417, No. 6891, 2002, pp. 822-828. doi:10.1038/nature00786

[19] M. Donoghue, F. Hsieh, E. Baronas, K. Godbout, M. Gosselin, N. Stagliano, et al., "A Novel Angiotensin-Converting Enzyme-Related Carboxypeptidase (ACE2) Converts Angiotensin I to Angiotensin 1-9," Circulation Research, Vol. 87, No. 5, 2000, pp. E1-E9. doi:10.1161/01.RES.87.5.e1

[20] M. C. Chappell, N. T. Pirro, A. Sykes and C. M. Ferrario, "Metabolism of Angiotensin-(1 - 7) by Angiotensin-Converting Enzyme," Hypertension, Vol. 31, No. 1, 1998, pp. 362-367. doi:10.1161/01.HYP.31.1.362

[21] K. Yamada, S. N. Iyer, M. C. Chappell, D. Ganten and C. M. Ferrario, "Converting Enzyme Determines the Plasma Clearance of Angiotensin-(1 - 7)," Hypertension, Vol. 32, No. 3, 1998, pp. 496-502. doi:10.1161/01.HYP.32.3.496 
[22] R. A. Santos, A. C. Simoes e Silva, C. Maric, et al., "Angiotensin-( 1 - 7) Is an Endogenous Ligand for the G Protein-Coupled Receptor Mas," Proceedings of the National Academy of Sciences of the United States of America, Vol. 100, No. 14, 2003, pp. 8258-8263. doi:10.1073/pnas.1432869100

[23] C. R. Nakaie, E. G. Silva, E. M. Cilli, R. Marchetto, S. Schreier, T. B. Paiva and A. C. Paiva, "Synthesis and Pharmacological Properties of TOAC-Labeled Angiotensin and Bradykinin Analogs," Peptides, Vol. 23, No. 1, 2002, pp. 65-70.

[24] G. N. Jubilut, E. M. Cilli, E. Crusca, E. H. Silva, Y. Okada and C. R. Nakaie, "Comparative Investigation of the Cleavage Step in the Synthesis of Model Peptide Resins: Implications for Nalpha-9-Fluorenylmethyloxycarbonyl-Solid Phase Peptide Synthesis," Chemical \& Pharmaceutical Bulletin (Tokyo), Vol. 55, No. 3, 2007, pp. 468-470.

[25] D. E. Morbeck, P. C. Roche, H. T. Keutmann and D. J. McCormick, "A Receptor Binding Site Identified in the Region 81-95 of the Beta-Subunit of Human Luteinizing
Hormone (LH) and Chorionic Gonadotropin (hCG)," Molecular and Cellular Endocrinology, Vol. 97, No. 1-2, 1993, pp. 173-181.

[26] S. M. R. Noronha, S. A. A. Correa-Noronha, I. H. Russo, R. L. di Cicco, J. Santucci-Pereira and J. Russo, "Human Chorionic Gonadotropin and a 15 Amino Acid hCG Fragment of the Hormone Induce Downregulation of the Cytokine IL-8 Receptor in Normal Breast Epithelial Cells," Hormone Molecular Biology and Clinical Investigation, Vol. 6, No. 3, 2011, pp. 241-245.

[27] Y. Zhao, X. Chen, L. Cai, Y. Yang, G. Sui and S. Fu, "Angiotensin II/angiotensin II Type I Receptor (AT1R) Signaling Promotes MCF-7 Breast Cancer Cells Survival via PI3-Kinase/Akt Pathway," Journal of Cellular Physiology, Vol. 225, No. 1, 2010, pp. 168-173.

[28] W. J. Petty, M. Aklilu, V. A. Varela, J. Lovato, P. D. Savage and A. A. Miller, "Reverse Translation of Phase I Biomarker Findings Links the Activity of Angiotensin-(1 - 7) to Repression of Hypoxia Inducible Factor-1Alpha in Vascular Sarcomas,” BMC Cancer, Vol. 12, No. 1, 2012, p. 404. 